\title{
PENGEMBANGAN POTENSI KAWASAN AGROWISATA PULAU KALEDUPA DI KABUPATEN WAKATOBI
}

\author{
Muhammad Yusri Lukman ${ }^{1}$, Muhammad Zaki ${ }^{2,}$ A. M. Ikhsan ${ }^{3}$ \\ ${ }_{1,2,3}$ Program Studi Arsitektur, Universitas Muslim Indonesia \\ E-mail Penulis Korespondensi: yoesluk@yahoo.com, aqee98@gmail.com
}

\begin{abstract}
Abstrak
Kabupaten Wakatobi merupakan daerah yang kaya akan potensi wilayahnya baik itu sumber daya alam, peninggalan sejarah, seni dan budaya yang dapat menjadi daya tarik wisata. Pulau Kaledupa sebagai salah satu pulau utama di Kabupaten Wakatobi memiliki potensi sebagai salah satu destinasi pariwisata karena memiliki keunggulan karakterisitik pantai, pulau-pulau kecil, bawah laut dan situs sejarah maupun budayanya. Kegiatan agrowisata itu sendiri bertujuan untuk memperluas wawasan pengetahuan, pengalaman rekreasi dan hubungan usaha di bidang pertanian yang meliputi tanaman pangan, holtikultura, perkebunan, perikanan dan peternakan. Metode penelitian yang digunakan dalam penelitian ini yaitu metode kualitatif dengan pendekatan rancangan kawasan. Dalam penelitian ini yang akan diteliti adalah difokuskan pada Pengembangan Agrowisata tanaman pangan dan hortikultura dengan mengintegrasikan tanaman perkebunan dan kehutanan serta perikanan dan peternakan. Temuan penelitian : (1). Delineasi kawasan sebagai salah satu wilayah yang akan dikembangkan sebagai Kawasan Agrowisata. (2). Hasil analisis potensi kawasan yang potensial untuk Pengembangan Kawasan Agrowisata (dilihat dari aspek teknis, sosial, ekonomi, budaya dan lingkungan alam). (3).Penentuan dan Pemetaan komponen-komponen yang perlu dibangun/ dikembangkan serta tahapan pelaksanaannya dalam rangka pengembangan wilayah yang bersangkutan sebagai Kawasan Agrowisata yang berdaya saing dan berkelanjutan. (4).Tersusunnya perencanaan Tata Ruang dan Tata Guna Lahan. (5).Tersusunnya rekomendasi pola manajemen Agrowisata.
\end{abstract}

Kata Kunci: Potensi, Kawasan, Agrowisata.

\section{PENDAHULUAN}

Pariwisata memiliki peran besar dalam pembangunan nasional. Sektor pariwisata berperan dalam mendorong pertumbuhan sektor lainnya melalui pengembangan sarana dan parasarana di daerah yang menjadi tujuan wisata. Selain itu, usaha pengembangan pariwisata yang berkelanjutan jika direncanakan dengan baik dapat berkontribusi dalam pencapaian Tujuan Pembangunan Milenium Indonesia, termasuk pengurangan kemiskinan, pembangunan perdesaan, pelestarian budaya dan masyarakat, kesetaraan jender, perlindungan lingkungan, mitigasi perubahan iklim dan memperlihatkan dampak yang bermanfaat terhadap mitigasi perubahan iklim.

Pulau Kaledupa sebagai salah satu pulau utama di Kabupaten Wakatobi memiliki potensi sebagai salah satu destinasi pariwisata karena memiliki keunggulan karakterisitik pantai, pulau-pulau kecil, bawah laut dan situs sejarah maupun budayanya. Dalam rangka memanfaatkan potensi yang dimiliki Pulau Kaledupa untuk meningkatkan ekonomi daerah maupun masyarakat tanpa mengeksploitasi secara berlebihan potensi yang ada, pengembangan dan perencanaan pariwisata Pulau Kaledupa yang berkelanjutan perlu dilakukan dengan penggunaan konsep agrowisata terpadu.

Agrowisata merupakan salah satu jenis pariwisata yang memanfaatkan potensi pertanian sebagai obyek wisata, baik potensi berupa pemandangan alam kawasan pertaniannya maupun kekhasan dan keanekaragaman aktivitas produksi dan teknologi pertanian serta budaya masyarakat petaninya. Kegiatan agrowisata itu sendiri bertujuan untuk memperluas wawasan pengetahuan, pengalaman rekreasi dan hubungan usaha di bidang pertanian yang meliputi tanaman pangan, holtikultura, perkebunan, perikanan dan peternakan.

Berdasarkan Peraturan Pemerintah No. 50 Tahun 2011 Tentang Rencana Induk Pembangunan Kepariwisataan Nasional Tahun 2010-2025, Kabupaten Wakatobi merupakan satu-satunya wilayah di Provinsi Sulawesi Tenggara yang ditetapkan sebagai Kawasan Strategis Pariwisata Nasional (KSPN) dan diharapkan menjadi lokomotif dan penggerak pembangunan kepariwisataan yang tidak hanya penting bagi Kabupaten Wakatobi sendiri tetapi juga dalam skala Provinsi Sulawesi Tenggara dan nasional.

Pulau Kaledupa yang merupakan bagian dari wilayah administrasi Kabupaten Wakatobi teridiri dari dua kecamatan yaitu Kecamatan Kaledupa dan Kecamatan Kaledupa Selatan. Berdasarkan RTRW Kabupaten Wakatobi (Perda Kabupaten Wakatobi No. 12 Tahun 2012), kawasan peruntukkan pariwisata di Pulau Kaledupa yaitu kawasan pariwisata Hoda di Kecamatan Kaledupa dan kawasan pariwisata Peropa di Kecamatan Kaledupa Selatan, dimana obyek wisata yang dimiliki yaitu panorama bawah laut dan pantai, perbukitan/hutan, goa-goa alam dan hutan baku, serta sejarah dan budaya.

Penetapan Kabupaten Wakatobi sebagai Taman Nasional Laut tentunya menuntut perlakuan khusus dalam hal konservasi kawasan untuk menjaga kelestarian sumber daya alam Wakatobi. Terlebih lagi sebagai ekosistem pulau-pulau kecil, Wakatobi sangat rentan terhadap kerusakan ekosistem yang 
berakibat pada hilangnya spesies tertentu, sementara kehilangan spesies akan mengurangi kualitas ekosistem dan berdampak panda penurunan jumlah pengunjung.

Kontribusi sektor pariwisata Kabupaten Wakatobi bagi pendapatan daerah pada tahun 20052010 adalah terbesar kedua setelah sektor perikanan dan kelautan, tetapi manfaatnya bagi ekonomi lokal dan masyarakat setempat masih perlu ditingkatkan (Rencana Pengelolan Pariwisata Wakatobi). Oleh karena itu, pengembangan pariwisata harus dilakukan secara berkelanjutan agar tidak hanya dapat berkontribusi pada konservasi kawasan tetapi meningkatkan kesejahteraan masyarakat.

\section{ISI PENELITIAN}

\subsection{Metodologi Penelitian}

Metode penelitian yang digunakan dalam penelitian ini yaitu metode kualitatif dengan dengan pendekatan rancangan kawasan. Ruang lingkup wilayah studi dalam identifikasi pengembangan potensi kawasan agrowisata pulau kaledupa di kabupaten wakatobi, Sulawesi Tenggara meliputi wilayah Kawasan Pulau Kaledupa yang terdiri dari Kecamatan Kaledupa dan Kaledupa Selatan. Lingkup kegiatan ini difokuskan pada Pengembangan Agrowisata tanaman pangan dan hortikultura dengan mengintegrasikan tanaman perkebunan dan kehutanan serta perikanan dan peternakan.

Tahap analisa dalam identifikasi pengembangan potensi kawasan agrowisata pulau kaledupa di kabupaten wakatobi, Sulawesi Tenggara meliputi : 1.Analisa tapak dan lingkungan, 2. Analisa lahan, 3.Analisa tata bangunan, 4.Analisa ruang terbuka, 4 . Analisa infrastruktur, 5.Analisa perumusan program dan kegiatan.

Tahap Perumusan Rencana dalam identifikasi pengembangan potensi kawasan agrowisata pulau kaledupa di kabupaten wakatobi : (a). Perancangan tapak kawasan, mulai dari proses konsep hingga implementasi pengembangan, dengan didukung gambar secara 2 dimensi dan 3 dimensi. (b). Perencanaan sarana dan prasarana kawasan. (c). Perumusan program dan kegiatan. (d).Penataan pola ruang.

\subsection{Hasil Dan Pembahasan}

\section{Arah Pembangunan Pulau Kaledupa}

Perencanaan pembangunan wilayah ditujukan untuk mengupayakan keserasian dan keseimbangan pembangunan antar daerah sesuai dengan potensi alam yang dimiliki dan pemanfaatan potensi tersebut secara efisien, tertib dan aman. Pembangunan suatu wilayah erat hubungannya dengan penataan ruang, yang perlu diperhatikan dalam penataan ruang itu sendiri adalah bagaimana ruang harus dilihat sebagai satu kesatuan dan digunakan sebesar-besarnya untuk kemakmuran rakyat yang perlu dipelihara kelestariannya. Untuk itu, diperlukan suatu pendekatan penataan ruang wilayah yang mengatur hubungan yang harmonis antara sumber daya alam, buatan, dan manusia agar kinerja ruang meningkat untuk kesejahteraan masyarakat.

Jika meninjau kembali kebijakan Rencana Tata Ruang Wilayah Kabupaten Wakatobi, tujuan pembangunan wilayah Kabupaten Wakatobi adalah untuk mewujudkan tatanan ruang wilayah yang berorientasi pada sektor unggulan pariwisata dan perikanan-kelautan yang dapat mewujudkan kesejahteraan dan kemakmuran secara ekonomi bagi masyarakat dengan tetap memperhatikan kelestarian lingkungan hidup. Hal tersebut diwujudkan melalui kebijakan yang menetapkan bahwa Kabupaten Wakatobi sebagai Taman Nasional Laut. Status Kabupaten Wakatobi sebagai Taman Nasional Laut tersebut tentunya memerlukan perlakuan khusus dalam hal pengembangan kawasannya guna menjaga kelestarian sumber daya alam Kabupaten Wakaktobi.

Begitu pula dengan Pulau Kaledupa yang merupakan salah satu wilayah kecamatan dari daerah otonom Kabupaten Wakatobi yang juga merupakan wilayah Taman Nasional Kepulauan Wakatobi (TNKW). Tentu saja dengan visi pembangunan dan penetapan Kabupaten Wakatobi sebagai Taman Nasional Laut tersebut, akan berdampak pada arah pembangunan Pulau Kaledupa. Sumber daya alam yang dimiliki Pulau Kaledupa tentu saja akan dieksplorasi dan dimanfaatkan guna mendukung fungsi kawasan Kabupaten Wakatobi sebagai Taman Nasional Laut.

Untuk menyeimbangkan antara pelestarian lingkungan dan pemanfaatan potensi kawasan Pulau Kaledupa dalam pembangunan wilayah, maka perlu adanya arahan penataan ruang yang mampu mengintegrasikan dan mewujudkan perlindungan fungsi ruang serta pencegahan dampak negatif terhadap lingkungan akibat pemanfaatan ruang. Hal tersebut telah diatur dalam Rencana Tata Ruang Wilayah Kabupaten Wakatobi Tahun 2012-2032. Adapun arah pengembangan Pulau Kaledupa berdasarkan rencana pola ruang kabupaten adalah sebagai berikut:

1. Pulau Kaledupa merupakan bagian dari Kawasan Hutan Lindung seluas $\pm 570,03$ ha mencakup bagian Timur dan Selatan Pulau Kaledupa, bagian Utara Pulau Lentea, bagian Timur dan Selatan Pulau Darawa di Kecamatan Kaledupan dan Kaledupan Selatan;

2. Pulau Kaledupa sebagai kawasan resapan air yang diarakahkan pada kawasan hutan Sandi di Kecamatan Kaledupa Selatan dengan luas kurang lebih 72,71 ha.

3. Pulau Kaledupa ditetapkan sebagai kawasan perlindungan setempat yaitu termasuk kawasan sempadan sungai.

4. Pulau Kaledupa termasuk alam kawasan suaka alam, pelestarian alam dan cagar budaya yang 
tergolong dalam rencana kawasan pantai berhutan bakau.

5. Pulau Kaledupa ternasuk dalam perencanaan kawasan peruntukan hutan rakyat dengan luas $\pm 1.883,5$ ha.

6. Pulau Kaledupa termasuk dalam perencanaan kawasan pertanian tanaman pangan.

7. Pulau Kaledupa termasuk dalam perencanaan kawasan pertanian holtkultura.

8. Pulau Kaledupa merupakan kawasan perencanaan perkebunan yang mengandalkan komoditas kelapa, jambu mete, kakao, cengkeh, dan perkebunan campuran.

9. Pulau Kaledupa termasuk dalam perencanaan kawasan peternakan.

10. Pulau Kaledupa termasuk dalam perencanaan kawasan perikanan, dengan fungsi sebagai budidaya perikanan dan kawasan pengolahan ikan.

11. Pulau Kaledupa termasuk dalam perencanaan kawasan peruntukan pertambangan dan industri.

12. Pulau Kaledupa termasuk dalam perencanaan kawasan pariwisata yang lokasi terletak di Pulau Hoga Kecamatan Kaledupa dan Pulau Peropa di Kecamatan Kaledupa Selatan.

13. Ditetapkan sebagai perencanaan kawasan permukiman perkotaan dan perdesaan.

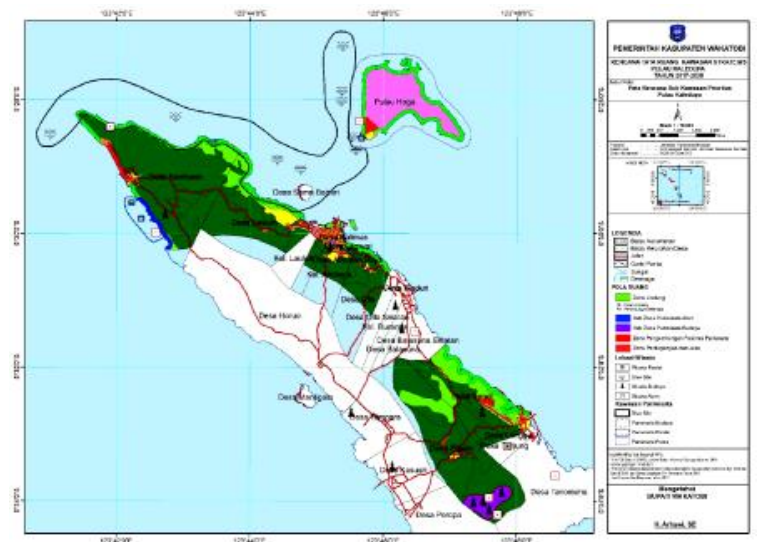

Gambar.1 Peta Kawasan Prioritas Kawasan Strategis Kaledupa Sumber : Dokumen KSK 2017

\section{Pariwisata}

Sektor pariwisata merupakan sektor andalan yang merupakan potensi ekonomi terdepan dalam mendukung pengemangan agrowisata di Puau Kaledupa. Motto Wakatobi sebagai daerah"surga nyata bawah laut di pusat segitiga karang dunia" menjadikan daerah ini menjadi tujuan wisata dewasa ini. Hal ini tentu saja berkaitan dengan tersedianya akomodasi yang memadai guna memberikan daya tarik bagi wisatawan. Perkembangan jumlah fasilitas akomodasi secara tidak langsung menunjukan perkembangan pariwisata. Hal ini secara ekonomi dikenal dengan hukum penawaran dan permintaan pariwisata. Fasilitas akomodasi di Kecamatan Kaledupa meliputi 3 usaha, 163 kamar, dan 467 tempat tidur pada tahun 2014. Pada tahun 2014, di
Kaledupa telah terdapat 1 unit penginapan, dan 2 unit resort. Jumlah kamar pada fasilitas akomodasi tersebut naik dibanding tahun sebelumnya. Kaledupa terkenal dengan pulau hoga yang menjadi pusat dive Internasional. Setiap tahun ratusan peneliti dari dalam dan luar negeri berkunjung ke pulau Hoga untuk meneliti ekosistem laut di pulau tersebut. Kunjungan wisatawan ke pulau hoga terus menunjukan peningkatan setiap tahunnya. Pada tahun 2014, ada sekitar 1.516 wisatawan yang berkunjung ke Kaledupa dan sekitarnya. Sedangkan di Kecamatan Kaledupan Selatan sejumlah penginapan tersedia untuk para pengunjung atau wisatawan asing maupun domestik. Sayangnya, fasilitas berupa hotel belum tersedia di kecamatan ini. Kendati demikian, sejumlah sarana akomodasi yang ada diharapkan dapat menarik minat para wisatawan(Kecamatan Kaledupa dalam Angka, 2016; Kecamatan Kaledupa Selatan dalam Angka, 2016).

Agro wisata yang dibina secara baik dengan memperhatikan dan mendasarkan kepada kemampuan masyarakat, akan memberikan dampak bagi peningkatan ekonomi masyarakat, dalam bentuk pendapatan masyarakat, kesempatan kerja, kesempatan berusaha. Beberapa keuntungan ekonomi tersebut dapat dijelaskan sebagai berikut:

1) Meningkatkan pendapatan masyarakat ; Hal ini erat kaitannya dengan berbagai kegiatan penjualan dari hasil cocok tanam, seperti sayursayuran, buah-buahan, bunga, palawija, ikan, susu dan lain-lain baik yang dijual secara langsung kepada pengunjung maupun hasil yang dijual untuk memenuhi kebutuhan masyarakat umum, di pasarpasar tradisional, super market. Khususnya pendapatan langsung yang dihasilkan dari pembelian langsung oleh wisatawan di lokasi agrowisata, memberikan dampak yang cukup luas terhadap kelangsungan dan keberadaan agro wisata.

2) Membuka kesempatan berusaha; Keanekaragaman jenis agro wisata telah mengembangkan lahan yang diperuntukkan bagi kegiatan bercocok tanam masyarakat. Berbagai jenis komoditi bagi wisatawan disediakan masyarakat pada lahan-lahan yang memiliki latar belakang ke-indahan, kesejukan, kenyamanan sehingga para pengunjung dapat melakukan rekreasi di lokasi-lokasi yang dipersiapkan untuk agro wisata. Dengan berkembangnya jumlah wisatawan/pengunjung ke lokasi agro wisata akan memberikan pengaruh efek ganda dalam mengembangkan usaha masyarakat baik dalam bentuk hasil komoditi pertanian, maupun makanan olahan yang dihasilkan oleh hasil pertanian, perikanan maupun peternakan. Efek ganda dengan tumbuh kembangnya agro wisata memungkinkan dapat mendorong kesempatan berusaha masyarakat yang pada gilirannya dapat mendongkrak faktor 
kemiskinan yang pada saat ini menjadi permasalahan bagi bangsa Indonesia.

3) Meningkatkan produksi dan kualitas; Peningkatan hasil produksi pertanian merupakan acuan dasar bagi tumbuh berkembangnya sektor pertanian dan sejenisnya. Pengelolaan agro wisata dengan baik, setidaknya akan berpengaruh terhadap peningkatan produksi masing-masing komoditas yang diusahakan. Di samping itu kualitas dari komoditas yang diusahakan yang dihasilkan oleh pengelola agro wisata, sangat selektif dan menjadi perhatian pengelola. Segala sesuatu yang disajikan harus memiliki kualitas, mengingat para wisatawan yang membeli hasil pertanian dan sejenisnya akan mengkonsumsi dan membeli langsung.

Berdasarkan RTRW Kabupaten Wakatobi, Pulau Kaledupa termasuk sebagai Kawasan Strategis Kabupaten (KSK) dengan fungsi sebagai kawasan pengembangan kebudayaan pariwisata Kaledupa. Kawasan ini arahannya dikembangkan untuk mendorong peningkatan dan pelestarian nilai-nilai sosial budaya, meningkatkan kecintaan masyarakat akan nilai-nilai sosial budaya yang mencerminkan jati diri masyarakat, serta penerapan nilai budaya dalam kehidupan masyarakat dan pengembangan pariwisata.

\section{a. Daya Tarik Wisata Alam Perairan Laut \\ 1) Pantai Hoga}

Pantai Hoga merupakan sebuah pantai yang sangat indah. Terdapat di sebelah utara Pulau Kaledupa. Pantai ini statusnya milik pemerintah. Dapat di akses dengan menggunakan perahu bermotor sekitar 15 menit dari Dermaga Ambeua Kaledupa. Pantai ini memiliki kualitas pasir dan air laut yang sangat bagus dengan tingkat abrasi yang sedang. Memiliki karakter gelombang yang agak keras. Rata-rata kunjungan ke pantai ini sekitar 2000/tahun. Wisatawan yang dominan datang ke pantai ini adalah Eropa terutama Inggris.

Kawasan ini sudah memiliki badan penyelamat pantai. Di Pantai Hoga ini kita dapat menikmati indahnya matahari terbit dan matahari tenggelam. Jenis-jenis kegiatan wisata di pantai itu adalah diving, snorkeling, dan lain sebagainya. Di pantai itu kita bisa menemukan rumah adat yang sekarang dijadikan sebagai homestay dan restoran. Fasilitas wisata/ekowisata yang telah berkembang di Pantai Hoga adalah sebagai berikut:

- Stasiun Penelitian "Marine Research Station" yang dikelola oleh kerjasama antara Operation Wallacea dan Kementerian Kehutanan (Taman Nasional Wakatobi). Lembaga ini mewadahi kegiatan wisata berbasis research dibidang marine biology (terumbu karang, lamun, ikan); kegiatan training dive, diving, social culture.

- Homestay, sebanyak 148 buah, yang dikelola oleh masyarakat lokal (Bajo Kaledupa). Diantara homestay dibuat jalan setapak yang, jalan ini juga berfungsi untuk wisatawan yang ingin menikmati pemandangan/vegetasi alam didaratan hoga.

- Hotel "Hoga Dive Resort", resort ini dibangun dengan style rumah panggung berbahan kayu, dilengkapi dengan fasilitas restoran, mulai beroperasi tahun 2014 dimiliki oleh suasta (masyarakat lokal Sulawesi). Jumlah kamar sebanyak 20 dengan harga perkamar berkisar dari Rp 500.000-800.000 per hari. Tamu yang banyak menginap di hotel ini adalah wisnu dan mancanegara (terutama Eropa).

\section{2) Pantai Sombano}

Terletak di Desa Sombano, Kecamatan Kaledupa, sekitar $9 \mathrm{Km}$ dari Ambeua. Dapat ditempuh dengan kendaraan roda dua maupun roda empat. Kawasan ini berstatus milik masyarakat. Kualitas pasir dan air laut pantai ini sangat bagus. Hamparan pohon kelapa disepanjang pantai. Pada musim-musim tertentu, gelombang dan arus laut sangat kuat. Kawasan ini memilki tingkat abrasi yang rendah. Pantai Sombano memiliki hamparan pasir putih yang bersih, vegetasi pantai yang rapat, serta dapat menikmati sunset di saat senja sambil menikmati semilir angin yang berhembus dari dedaunan nyiur yang melambai. Kawasan ini belum memilki badan penyelamat pantai. Kita dapat menikmati pemandangan sunset dari pantai ini. Jenis-jenis biota laut yang terdapat di kawasan ini antara lain mata tujuh, kima, ikan, bintang laut dan bulu babi. Oleh masyarakat setempat Pantai ini juga digunakan untuk lokasi bertani rumput laut dan menangkap ikan. Tiap tahun, jumlah wisatawan yang berkunjung ke kawasan ini sekitar 500 orang. Fasilitas akomodasi belum tersedia di pantai ini.

\section{3) Pantai Peropa}

Pantai Peropa merupakan objek daya tarik wisata yang ada di Desa Peropa. Jarak tempuh menuju pantai ini kurang lebih $9 \mathrm{~km}$ dari Ibukota kecamatan atau \pm 30 menit, dapat ditepuh dengan menggunakan kenderaan roda dua maupun roda empat. Pantai ini memiliki kualitas air laut dan pasir yang cukup bagus. Di pantai ini juga wisatawan dapat menikmati panorama matahari terbenam (sunset). Selain itu juga dapat menyaksikan aktivitas masyarakat Desa Peropa yang menangkap ikan dengan menggunakan alat-lat tradisional seperti Sero. Sero adalah alat tangkap ikan yang terbuat dari bambu yang dijejer rapi memanjang. Pantai ini juga digunakan sebagai tempat tambatan perahu bagi para nelayan setempat, persinggahan para nelayan.

Di pantai ini telah memiliki fasilitas yang dibuat oleh masyarakat setempat seperti bale-bale, sejenis balai dari bambu yang digunakan wisatawan sebagai tempat melepas lelah sambal menikmati semilir angin yang berhebus dari daun kelapa, dimana di pantai tersebut masih terdapat pohon kelapa dan beberapa pohon lainnya. 


\section{4) Pantai Langira}

Terletak di Desa Sombano. Dapat ditempuh dengan kendaraan roda dua, roda empat dan perahu bermotor. Terletak sekitar $9 \mathrm{~km}$ dari Ambeua. Status kawasan ini milik masyarakat. Kualitas pasir dan air lautnya sangat bagus. Pada musim-musim tertentu, gelombang dan arus laut sangat kuat. Memiliki tingkat abrasi yang sangat rendah. Pantai ini belum memiliki badan penyelamat pantai. Keindahan sunrise dan sunset bisa dinikmati di pantai ini. Jenisjenis biota laut yang terdapat di kawasan ini adalah bulu babi, kima, bintang laut, ikan, mata tujuh, dan lain-lain.

Fasilitas akomodasi belum tersedia di pantai ini. Selain pantai dengan pasir putih, kawasan ini memilki keunikan lain seperti memiliki hutan bakau dengan kualitas tinggi. Jumlah wisatawan yang berkunjung ke tempat ini sekitar 100 orang/tahun.

\section{5) Pantai One Mbih}

Pantai ini masuk dalam kawasan Desa Darawa. Bisa ditempuh dengan menggunakan perahu bermotor sekitar 30 menit dari Ambeua. Pantai ini memiliki kualitas pasir dan air laut yang bagus. Karakter arus dan gelombang di pantai ini sangat tenang. Namun, pada musim-musim tertentu, gelombang dan arus laut sangat kuat. Di pantai ini kita dapat melihat indahnya sunrise. Daerah ini sering dijadikan masyarakat setempat sebagai tempat wisata dan tempat pemakaman umum. Jumlah kunjungan wisatawan baik asing maupun domestik sekitar 300 orang.

\section{6) Danau Air Asin Sombano}

Danau Sombano terletak di Desa Sombano sekitar $10 \mathrm{~km}$ dari Ambeua. Dapat di akses dengan menggunakan kendaraan roda dua dan dilanjutkan dengan berjalan kaki sekitar $2 \mathrm{~km}$. Juga dapat di tempuh dengan menggunakan perahu bermotor. Kualitas air telaga ini bagus. Rasanya asin seperti air laut. Mempunyai kedalaman yang sedang dengan karakter arus yang tenang. Keindahan sunrise dan sunset dapat dinikmati dari telaga ini. Biota laut yang ada dan menjadi daya tarik tempat ini adalah udang merah serta terumbu yang indah. Belum memilki fasilitas akomodasi serta kebijakan pemerintah belum ada. Jumlah wisatawan yang berkunjung ke tempat ini sekitar 300 orang/tahun. Masyarakat menggunakan kawasan ini sebagai tempat rekreasi.

\section{7) Terumbu Karang dan Dive Spot}

Perairan sekitar Pulau Kaledupa memiliki terumbu karang yang indah dan panjang. Panjang gugusan terumbu karang Kaledupa mencapai 22,92 $\mathrm{Km}$ dan lebar mencapai 7,31 Km. Pertumbuhan karang dimulai pada kedalaman 2-4 meter yang berupa koloni-koloni kecil dengan keanekaragaman yang tinggi. Pada rataan terumbu didominasi oleh Porites cylindrica, Porites nigrescens dan Acropora polifera. Mendekati tubir, pertumbuhan karang semakin banyak dan beragam, yang didominasi oleh
Acropora acuminata, A. micropthalma, Pocillopora verrucosa.

Beberapa terumbu karang sekitar Pulau Kaledupa merupakan dive spot yang sangat menarik. Setidaknya terdapat 25 dive spots, tersebar di sekitar Pulau Hoga, Pulau Kaledupa. Beberapa karakter dive spot tersebut yaitu:

a) Kaledupa 1 dan Kaledupa 2

Kondisi umum sama dengan duble spoor, kondisi terumbu yang tidak terlalu bagus (banyak sedimentasi), namun banyak yang dapat dilihat, difoto dan diamati, misalnya: banyak terdapat lobster di gua-gua kecil, nudibrance, karang hias yang unik dan cantik.

b) Kaledupa Sombano

Kondisi tubir, soft coral di rataan 3 - 5 mulai tumbuh, kondisi karang yang tidak terlalu bagus, banyak serpihan karang dan pasir di beberapa tempat bekas bom. Terdapat ikan karang penghuni tebing seperti: triger kembang, naso, Achanturus sp., rombongan ikan Platax. Kondisi tebing dan gua-gua berdinding tebing yang eksotik dan menantang.

c) Kaledupa Ridge 1

Ikan melimpah, kondisi karang tidak bagus, arus kencang dan merupakan tempat pemijahan ikan kerapu (Epinephelus sp.). Site ini sangat cantik dengan ribuan ikan-ikan yang bermain di sekitar penyelam. Ditemukan juga rombongan ikan baracuda, bumphead (ikan Kakatua Berpunuk).

d) Kaledupa Out Pinaccel

Gosong karang atau pacthreef, berbagai jenis ikan dapat kita temui, umumnya topografi tubir, dengan berbagai jenis coral encrusting. Kita dapat menemukan ikan buaya, napoleon dan kerapu, dan lain-lain. Jika beruntung lokasi ini adalah merupakan tempat ikan baracuda bergerombol.

e) Kaledupa Kasim

Topografi slope, terdapat bebapa gua pada dinding, berbagai jenis ikan karang (baracuda, lepu ayam, bumphead, sweatlips, berbagai jenis Chaethodon dan lainnya) terumbu karang rusak / hancur, mulai mengalami recovery.

f) Kaledupa Double Spoor

Kondisi slope dan beberapa tempat tubir, kondisi karang tidak terlalu bagus, banyak guagua kecil dan kondisi terumbu tebing berlikuliku (zig zag), ikan cukup banyak.

g) Kaledupa Coral Garden

Kondisi karang yang cukup baik di 3 meter, umumnya kondisi topografi slope.

h) Kaledupa Buoy 2

Topografi slope, terdapat softcoral dan beberapa coral (masive, encrusting dan branching), kita bisa melihat ikan kakatua (bumphead) bermain dengan jinak. Cukup banyak jenis ikan karang dan jenis kerapu. 
b. Daya Tarik Wisata Alam Daratan

1) Goa Alam Darawa

Goa ini terletak di Desa Darawa, kecamatan Kaledupa Selatan. Memiliki bentuk yang masih alami dengan ukuran diameter 5 meter. Lokasi ini dapat ditempuh dengan menggunakan speedboat sekitar 45 menit dari Ambeua. Dahulu gua alam ini digunakan sebagai tempat persembunyian pada zaman Bonto Kaledupa masih berkuasa. Hal-hal unik yang dapat kita temui di gua ini adalah memiliki stalaktit, sarang kelelawar, sarang burung walet, kulit kima raksasa, ada bekas aliran sungai serta pohon beringin didekat mulut gua. Kondisi goa alam ini sangat baik. Jumlah kunjungan wisatawan ke goa ini sekitar 70 orang, baik itu wisatawan domestik maupun asing. Permasalahan yang sering dihadapi adalah pengelolaan yang kurang maksimal.

2) Goa Sangia Wagugu

Tempat ini terletak di Desa Langgee, Kecamatan Kaledupa. Dapat ditempuh dengan menggunakan kendaraan roda dua maupun roda empat, sekitar $8 \mathrm{Km}$ dari Ambeua. Kawasan ini memiliki ukuran sekitar 10 x 20 meter. Kondisinya masih bagus. Sering digunakan warga sebagai tempat pertapaan/semedi.

Konon, dahulu setiap malam Jumat sering terdengar tangisan di tempat ini sehingga dinamakan Sangia Wagugu (wagugu = orang menangis). Hal-hal unik yang dapat kita temui di tempat ini seperti: kuburan tua, pakani, bunga anggrek dan pohon beringin dengan akar menjuntai ke bawah. Jumlah wisatawan yang berkunjung ke tempat ini dalam setahun sekitar 50 orang. Kawasan ini belum dikelola dengan baik sebagai tempat wisata.

3) Watu Meleu

Terletak di Desa Langge. Dapat ditempuh dengan menggunakan kendaraan roda dua sekitar $8 \mathrm{Km}$ dari Ambeua. Kawasan ini memiliki luas sekitar 20 x 30 meter.Jumlah wisatawan yang berkunjung ke tempat ini sekitar 500 orang/tahun Di sekitar tempat ini terdapat sebuah makam tua di atas batu karang. Inilah yang menjadi keunikan dari tempat ini. Digunakan warga sebagai tempat wisata.

4) Goa Sangia Akka Kuri-Kuri

Daerah ini terletak di Desa Sandi, sekitar 7 km dari Ambeua. Dapat dijangku dengan menggunakan kendaraan roda dua. Luas daerah ini sekitar $1 / 4$ hektar. Di tempat ini terdapat sebuah goa yang di dalamnya terdapat dua buah kuburan tua. Goa tersebut tembus ke laut. Tempat ini juga memiliki keunikan yaitu terdapat pohon bakau yang daunnya berwarna hijau kekuning-kuningan, berbeda dengan bakau pada umumnya. Jumlah wisatawan baik domestik maupun asing yang berkunjung ke tempat ini sekitar 200 orang/tahun. Kawasan ini belum di kelola dengan baik sebagai tempat wisata.

5) Goa Alam Sangka'a Nukiye

Pada zaman dahulu gua ini digunakan sebagai tempat berlindung /persembunyian dari gerombolan pengacau. Setelah tidak digunakan sebagai tempat persembunyian, gua ini digunakan oleh masyarakat sebagai tempat untuk menganyam tikar (sanka'a nukiye). Hawa sejuk langsung terasa saat kita sampai di gua ini. Kini gua yang dikenal juga dengan sebutan gua lembah sejuk ini menjadi tempat wisata. Letaknya di dusun Palea, Desa Pajam, Kecamatan Kaledupa Selatan. Dapat ditempuh dengan kendaraan roda dua sekitar $9 \mathrm{Km}$ dari Ambeua. Bentuk gua ini adalah ruang lapang yang berdiameter 8 meter. Kondisinya sangat terawat. Wisatawan yang bekunjung ke gua ini adalah sekitar 200 orang/tahun untuk wisatawan domestik dan sekitar 50 orang/tahun untuk wisatawan asing, Permasalahan yang dihadapi adalah pengelolan yang belum maksimal.

6) Perbukitan Pangilia

Perbukitan ini terletak di sebelah Timur Desa Pajam, Kecamatan Kaledupa Selatan. Statusnya adalah milik masyarakat. Tempat ini dapat ditempuh dengan kendaraan roda dua sekitar 9 $\mathrm{Km}$ dan dilanjutkan dengan berjalan kaki sekitar $4 \mathrm{Km}$. Kualitas udara di pegunungan ini masih bagus. Jenis flora yang terdapat di daerah ini padang belukar (semak belukar). Potensi ekologi yang dimiliki adalah hutan yang belum tereksploitasi. Di pegunungan Pangilia ini terdapat sebuah benteng kuno tetapi tinggal reruntuhannya saja. Jumlah wisatawan yang berkunjung ke tempat ini sekitar 300 orang/tahun. Belum memiliki fasilitas akomodasi serta kebijakan pemerintah sebagai penunjang destinasi wisata.

\section{Sosial Budaya}

a. Desa Pajam merupakan salah satu desa yang terletak di perbukitan Pulau Kaledupa. Desa ini merupakan salah satu desa yang tertua, letaknya yang berada pada ketinggian lebih dari 1000 mdpl ini memberikan pemandangan yang berbeda dari lokasi yang ada di Pulau Kaledupa. Desa menyimpan banyak situs budaya yang berpotensi untuk menambah keragaman pariwisata budaya di Kawasan Strategis Kaledupa.

b. Perkampungan tradisional Palea terletak di dusun Palea di wilayah Desa Pajam yang berjarak sekitar $9 \mathrm{Km}$ dari Ambeua. Akses jalan ke perkampungan ini relatif baik dan dapat ditempuh dengan kendaraaan roda dua dan empat. Perkampungan tradisional Palea merupakan perkampungan tertua dan tertinggi di Pulau Kaledupa, karena dibangun di atas bukit bebatuan yang terjal. Di samping pola 
perkampungan dengan arsitektur tradisionalnya yang unik, juga dapat disaksikan aktivitas kehidupan sehari-hari masyarakatnya yang khas

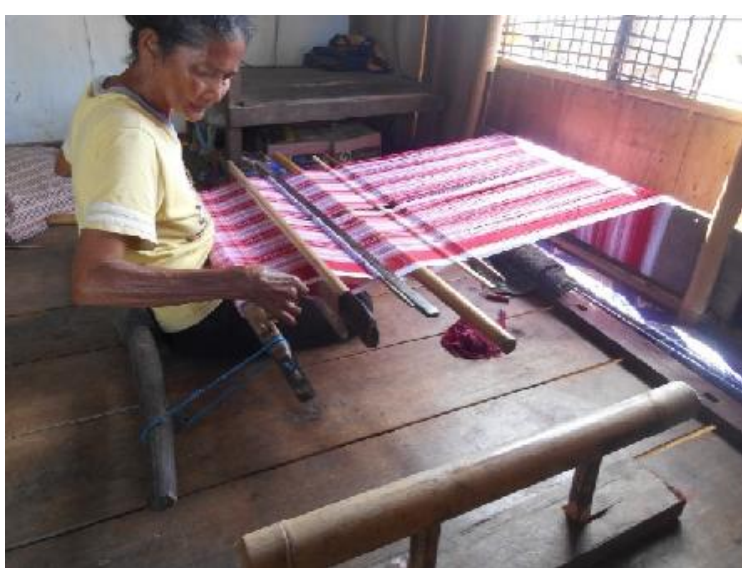

Gambar.2 kegiatan Menenun di Desa Pajam Sumber : Survey 2018

c. Letaknya pada perbukitan menjadikan lokasi ini sebagai tempat untuk menikmati matahari terbit dan terbenam
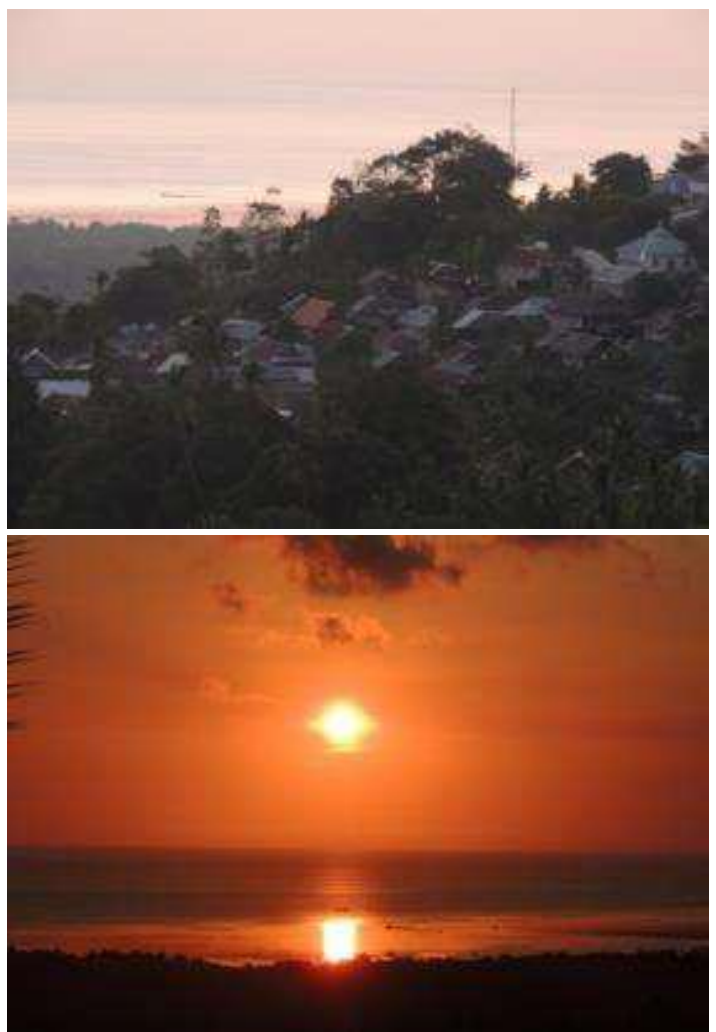

Gambar.3 Perkampungan di Desa Pajam (atas) Matahari Terbenam yang Dilihat Dari Desa Pajam (bawah)

\section{Arahan Rancangan}

Berdasarkan Renstra Dinas Pertanian Kabupaten Wakatobi Tahun 2017-2021, pembangunan pertanian dianggap merupakan bagian integral dari pembangunan nasional yang bertujuan untuk meningkatkan pendapatan dan kesejahteraan petani. Dalam mewujudkan pembangunan tersebut diperlukan adanya perencanaan pembangunan yang realistis dan rasional. Sementara itu, pembangunan pertanian di Kabupaten Wakatobi merupakan salah satu sektor yang cukup memberikan andil dalam memacu perekonomian masyarakat terutama petani di pedesaan. Oleh karena itu, sektor pertanian ini perlu mendapat perhatian dalam pengembangannya guna meningkatkatkan perannya dalam memacu keberhasilan pembangunan Kabupaten Wakatobi.

Salah satu usaha yang dapat diambil dalam mewujudkan pembangunan sektor pertanian yaitu melalui pemanfaatan sektor pertanian menjadi salah satu destinasi wisata dengan konsep agrowisata. Usaha ini tentu saja akan mendatangkan keuntungan tidak hanya bagi para petani tetapi juga bagi masyarakat luas, dan dengan adanya kegiatan pertanian berbasis pariwisata tentu saja akan menyerap tenaga kerja yang lebih banyak.

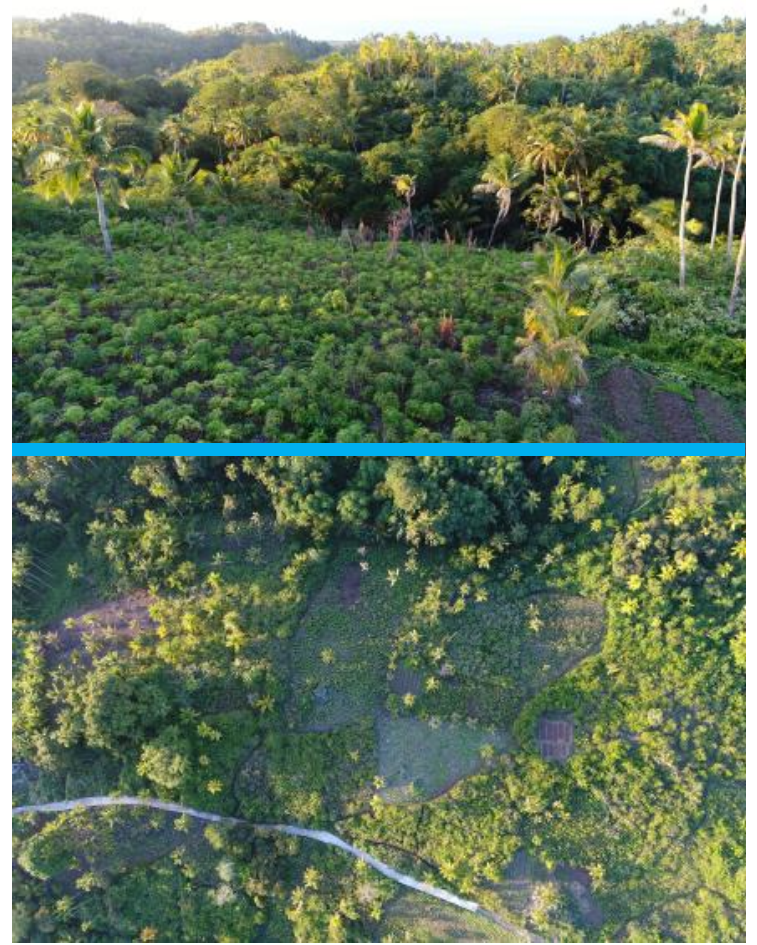

Gambar.4 Eksisting Kawasan Perencanaan Agrowisata Pulau Kaledupa di Desa Pajam

\section{a) Program Pariwisata}

Pengembangan Agrowisata yang menekankan pada budaya lokal dengan menjaga kelestarian alam dan lingkungan.

a) Program pelatihan dan pendidikan (SDM)

b) Program pengembangan kepariwisataan (produksi dan pemasaran)

c) Program pelestarian lingkungan (potensi SDA)

d) Program fasilitas dan layanan pariwisata (teknologi lokal)

b) Value

a) Partisipasi masyarakat

b) Keahlian dan Keterampilan 


\section{Jurnal Arsitektur, Kota dan Permukiman (LOSARI)}

c) Tradisi dan Budaya Tani

Pada dasarnya, pengembangan kawasan agrowisata memiliki tujuan untuk meningkatkan perekonomian petani lokal dengan membudidayakan produk pertanian bukan hanya untuk dijual mentah melainkan juga sebagai objek daya tarik wisata. Peningkatan perekonomian dapat dicapai melalui peningkatan jumlah wisatawan yang akan memberikan pemasukan melalui adanya insentif yang ditetapkan. Selain peningkatan ekonomi lokal, dengan melalui partisipasi masyarakat dimana masyarakat ini akan menjadi pihak yang mendapat pengaruh dari kegiatan wisata, diharapkan juga pengembangan wisata agro ini dapat menciptakaan meratanya kesejahteraan sosial di masyarakat.

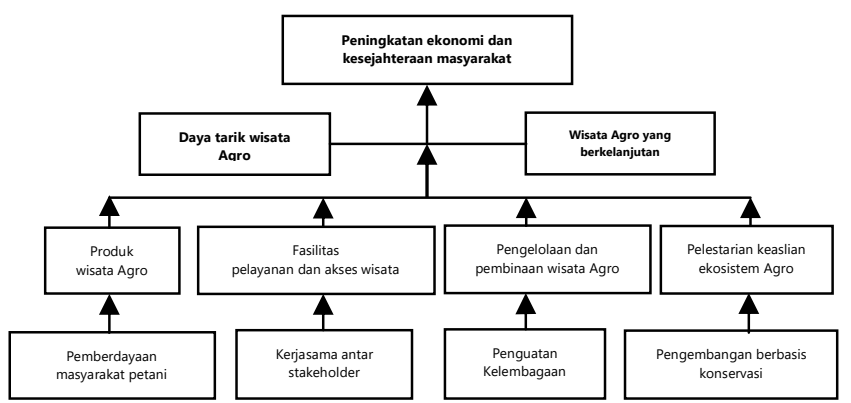

Gambar.5 Bagan Strategi Pengembangan Agrowisata

\section{Konsep Pengembangan Agrowisata Terpadu Pulau Kaledupa}

Agrowisata yang dikembangkan hendaknya mendukung upaya diversifikasi produk wisata yang mendukung fungsi Kawasan wisata dan sekaligus memperhatikan budi daya pertanian. Pengembangannya dilakukan berdasarkan potensi pertanian yang dimiliki dan peruntukan ruangnya sesuai dengan rencana tata ruang yang berlaku di masing-masing daerah, sehingga fungsi pariwisata dapat dilakukan sejalan dengan fungsi budidaya pertanian. Pengembangan kawasan wisata ini dilakukan melalui zonasi yang akan memberikan kualitas yang tinggi terhadap pengalaman pengunjung. Zona tersebut antara lain:

a. Zona inti yang di dalamnya terdapat kegiatan restorasi atau pemulihan sumberdaya. Area ini melakukan keunikan tersendiri dan produk khusus (core product). yang memiliki kegiatan dan fasilitas pengunjung atau wisatawan seperti restoran, pusat bisnis hotel, pelayanan informasi, panggung kesenian dan kebudayaan, dan lainnya

b. Zona penyangga lebih menitikberatkan dan memperkuat kesan nyaman dan memiliki nilai konservasi tinggi.

Berdasarkan potensi yang ada pengembangan agrowisata Pulau Kaledupa memanfaatkan potensi perkebunan. Selain itu, kearifan lokal yang ada di Kaledupa seperti kaombo/limbo serta tata cara pengelolaan sumberdaya masih dikenal dan dipraktekkan di beberapa desa sehingga menjadi potensi tersendiri bagi masyarakat Kaledupa. Budi daya tanaman perkebunan umumnya mencakup kegiatan-kegiatan antara lain:

a. Pengelolaan tanah, yakni kegiatan melakukan pembersihan lahan dari berbagai macam rumput, pohon, alang-alang yang dapat menganggu pertumbuhan bibit, juga akan menjamin kebersihan kebun yang dapat memberi daya tarik dan kenyamanan bagi wisatawan.

b. Pembibitan untuk menjamin tanaman tumbuh dengan baik dan seragam dengan menggunakan bibit yang baik. Metode pembibitan baik yang konvensional maupun menggunakan teknologi maju dapat menarik wisatawan, untuk itu perlu adanya areal pembibitan yang dapat dikunjungi oleh wisatawan.

c. Pemeliharaan tanaman perkebunan dengan metode khas dari masyarakat lokal dapat didemonstrasikan sebagai daya tarik wisata.

d. Pemetikan hasil perkebunan dapat menjadi kegiatan yang ditawarkan pada wisatawan.

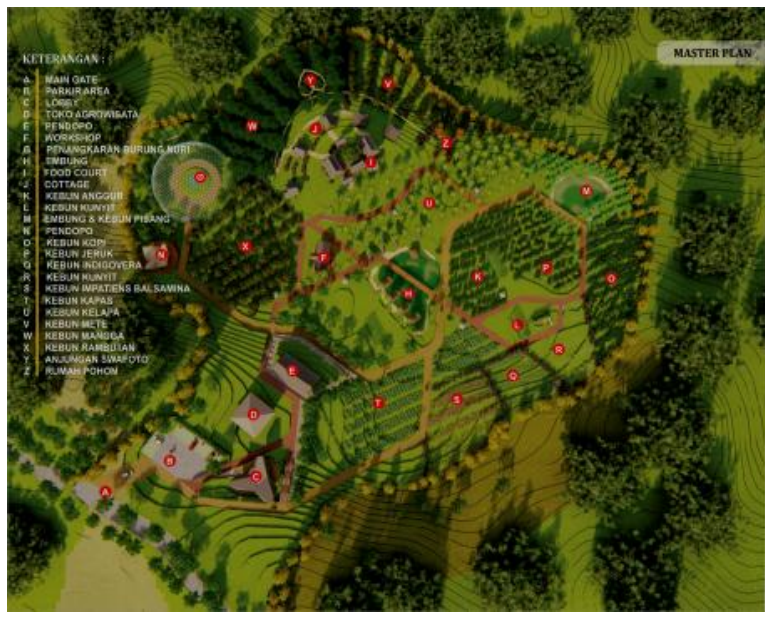

Gambar.6 Arahan Desain Pengembangan Agrowisata Pulau Kaledupa

Pendekatan pengembangan agrowisata di Pulau Kaledupa meliputi:

a. Pengembangan berbasis konservasi, dimaksudkan pola pembinaan yang tetap mempertahankan keaslian agro-ekosistem dengan mengupayakan kelestarian sumber daya alam lingkungan hidup, sejarah, budaya, dan rekreasi.

b. Pengembangan berbasis masyarakat, dimaksudkan pola pembinaan masyarakat yang menempatkan agrowisata sebagai pemberdayaan masyarakat petani untuk dapat memperoleh nilai tambah baik dari sisi hasil pertanian maupun dari kunjungan wisatawan dan efek ganda dari penyerapan hasil pertanian oleh usaha pariwisata dan pengembang.

c. Penetapan wilayah/daerah agrowisata sebagai daerah pembinaan. 
d. Visualisasi Pengembangan Agrowisata Terpadu Pulau Kaledupa

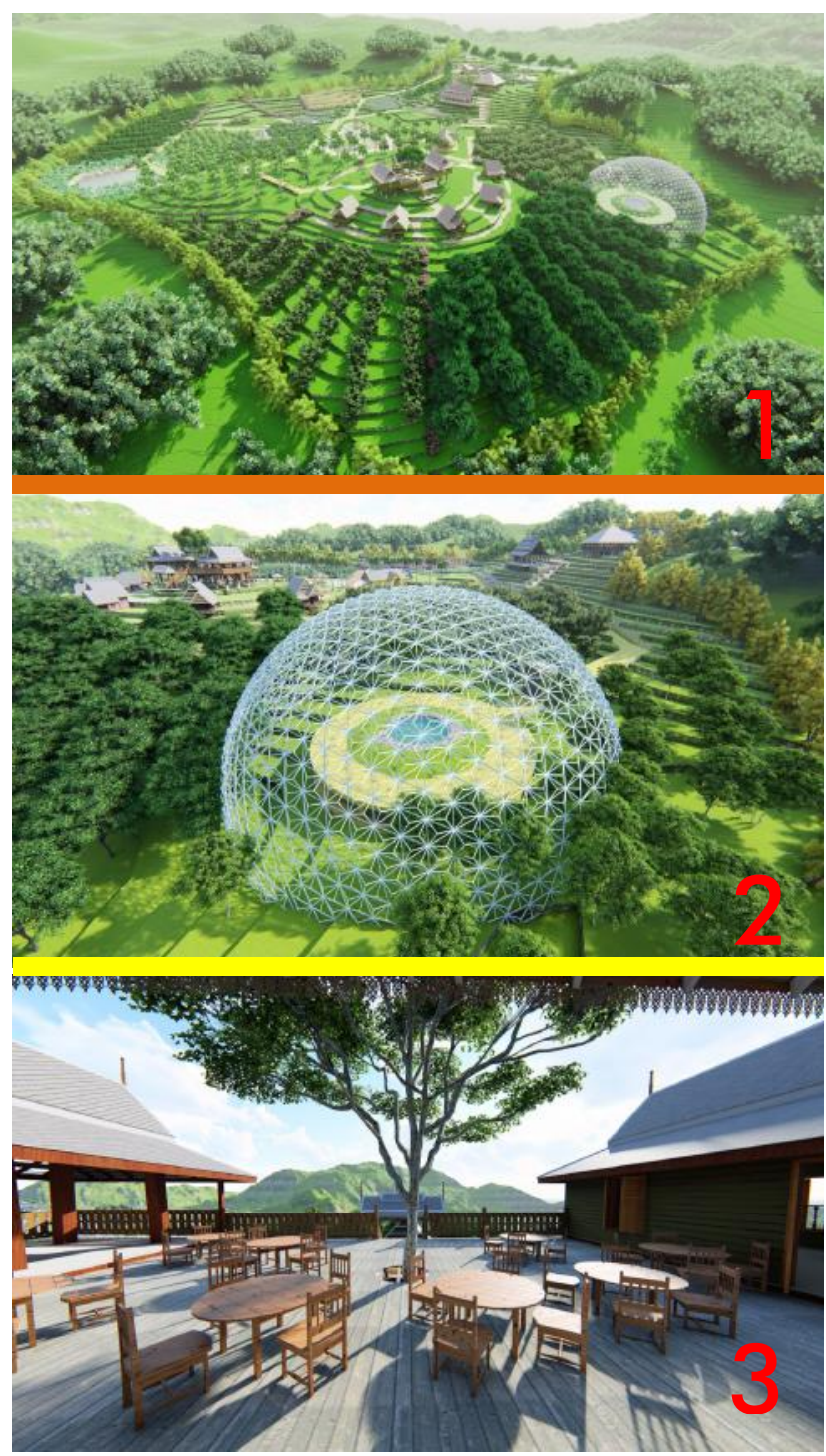

Gambar.7 Arahan Desain Pengembangan Agrowisata Pulau Kaledupa

\section{Rencana Program Pengembangan}

Berdasarkan kajian strategi implementasi, maka Rencana, program, dan pentahapan pengembangan Agrowisata Terpadu Pulau Kaledupa di Kabupaten Wakatobi untuk jangka waktu 5-10 tahun kedepan ini akan melibatkan tiga pihak pelaku pembangunan, yaitu pemerintah (kota/kecamatan/kelurahan, dan instansi terkait), pihak swasta (asita, phri, dan sebagainya), serta masyarakat yang interaksinya dibatasi oleh lembaga kontrol (Pers, DPRD, lembaga profesi/pakar). Dalam setiap indikasi program terdapat adanya dominasi kelembagaan (penanganan dan pelaksanaannya) yang menjadi motor utama pelaksanaan program.

Secara garis besar program pengembangan disusun berdasarkan dua tahapan waktu yaitu:

1. Tahap I : dilaksanaan dalam waktu 5 tahun mendatang dan ditentukan berdasar tingkat urgensi program tersebut dan kemungkinan realisasinya.

2. Tahap II : dilaksanakan dalam jangka waktu 10 tahun yang akan datang dengan tingkat urgensi yang lebih rendah dibandingkan dengan tahap II yang disesuaikan dengan kemampuan penangan dan kesiapan program.

\section{KESIMPULAN}

Berdasarkan dari hasil dan pembahasan di atas, maka dapat disimpulkan sebagai berikut:

\section{a. Program Pariwisata}

Pengembangan Agrowisata yang menekankan pada budaya lokal dengan menjaga kelestarian alam dan lingkungan.

- Program pelatihan dan pendidikan (SDM)

- Program pengembangan kepariwisataan (produksi dan pemasaran)

- Program pelestarian lingkungan (potensi SDA)

- Program fasilitas dan layanan pariwisata (teknologi lokal)

b. Value

- Partisipasi masyarakat

- Keahlian dan Keterampilan

- Tradisi dan Budaya Tani

\section{DAFTAR PUSTAKA}

Desain Pengembangan Produk dan Jasa yang Spesial untuk Agrowisata Sumber : Purwadi 2012

Kajian Teknis RIPPAR Provinsi Sulawesi Tenggara(2014)

Keputusan Direktur Jenderal Perlindungan Hutan dan Pelestarian Alam No. 198/Kpts/DJVI/1997 tanggal 31 Desember 1997, terdiri atas: zona inti, zona pelindung, zona rehabilitasi, zona pemanfaatan, dan zona pemanfaatan tradisional.

Perda Provinsi Sulawesi Tenggara No. 2 Tahun 2014 tentang RTRW Provinsi Sulawesi Tenggara, Kabupaten Wakatobi

Perda Provinsi Sulawesi Tenggara No. 2 Tahun 2014, arahan kebijakan dan rencana penataan ruang wilayah Provinsi Sulawesi Tenggara terhadap pembangunan kepariwisataan Kabupaten Wakatobi

World Tourism Organization (1996) dalam Fandeli dan Nurdin (2000: 27) 